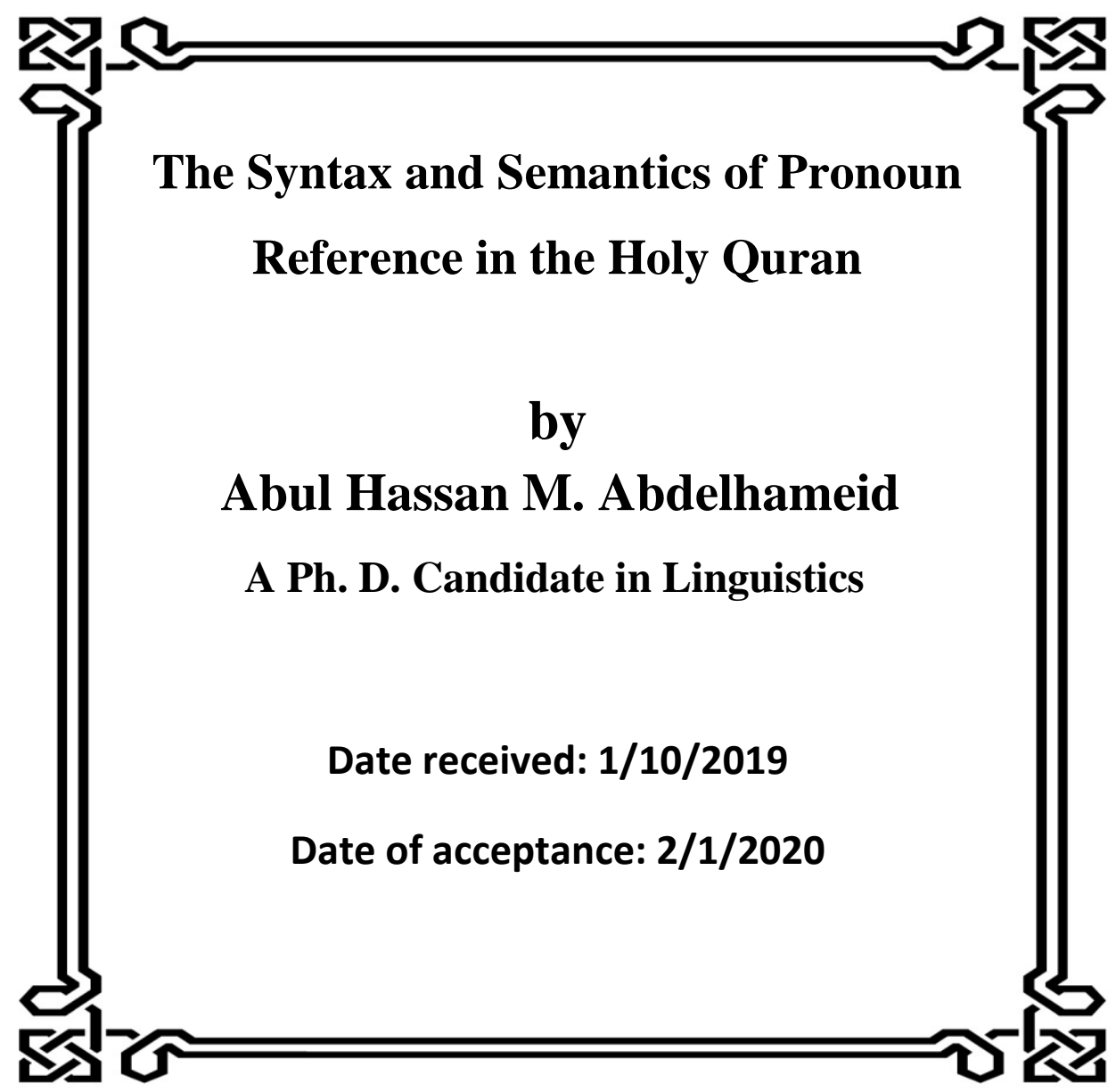





\section{The Syntax and Semantics of Pronoun Reference in the Holy Quran}

\section{Abstract}

Pronouns are parts of speech that stand for a noun or a noun phrase in order to avoid repetition and connect different parts of the text. Any text whatsoever, whether short or long, can hardly be found devoid of pronouns. Failure to identify the proper referent of a pronoun may lead to confusion, ambiguity and obscurity of meaning. Furthermore, identifying pronoun reference is crucial to the process of translation due to the fact that failing to identify the correct referent will inevitably lead to inaccurate translation.

The Holy Quran is characterized by frequent use of pronominal anaphora. Therefore, resolving pronoun reference is crucial to the understanding of the Holy Quran. Besides, recognizing the correct reference will help provide accurate renderings of the meanings of the Holy Quran with respect to the issue of pronoun reference. This paper addresses some of the semantic and syntactic rules of assigning pronoun reference in the Holy Quran.

The study reveals that reference switching is quite frequent in the Holy Quran. Arabic allows for reference switching, whereas English does not. Reference switching in Arabic occurs in person, number and gender. Besides, Arabic can allow for both lexical and semantic reference. English is strictly limited in this respect as it permits semantic reference only with collective nouns.

Key words: semantics, syntax, pronoun reference, Holy Quran, lexical form, lexical meaning

$$
\begin{aligned}
& \text { السمات النحوية و الدلالية لمرجعية الضمائر في القرآن الكريم }
\end{aligned}
$$

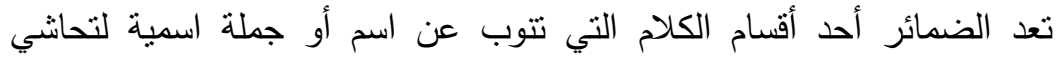

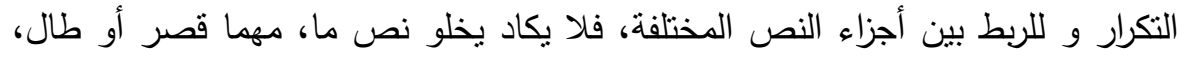

$$
\begin{aligned}
& \text { من الضمائر، وعدم القدرة على تعيين المرجع المناسب للضمير يؤدي إلى الالتباس }
\end{aligned}
$$

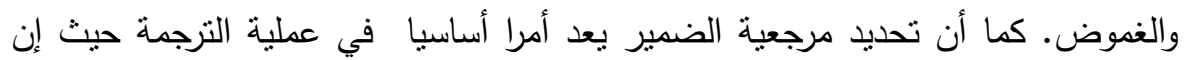

$$
\begin{aligned}
& \text { الإخفاق في تحديد المرجع الصحيح للضمير يقود حتما إلى ترجمة غير دقيقة. }
\end{aligned}
$$

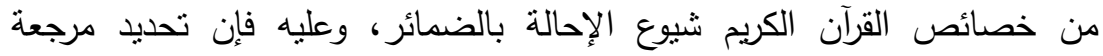

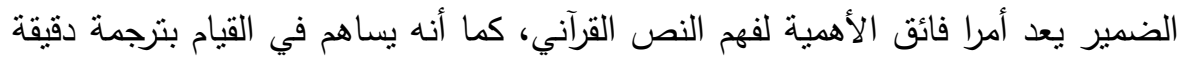

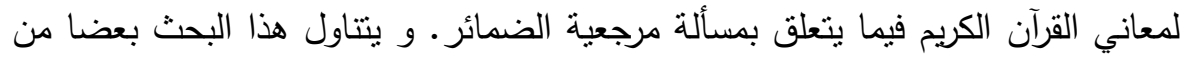

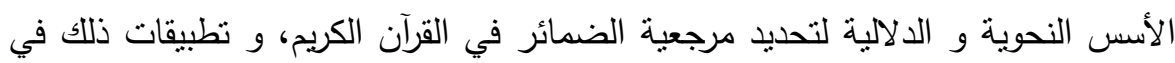

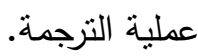




\section{Abul Hassan M. Abdelhameid}

\section{Introduction}

Crystal (2008) defines the pronoun as the term which can be used to substitute for a noun phrase or a single noun. Moreover, pronouns are considered a part of the connecting devices in a text as they replace explicit nouns and form cohesive ties that connect different parts of the discourse that will be otherwise incoherent. They serve to connect speech and avoid repetition, redundancy and boredom.

Personal pronouns refer to a noun or noun phrase which has already been mentioned or is familiar to the listener because it is obvious from the context. They refer to the people or things in the act of communication or connected to it in some way (Crystal 2008).

The Quran is the word of God revealed to the Prophet Mohammad through the Archangel Gabriel. It is the supreme authority in Islam and the fundamental source of the creed, rituals, ethics, and laws of the Islamic religion (Abdel Haleem, 2010: ix). The Quran is an approach of life governing the life of true Muslims as it includes the values, morals, codes of conduct and manners necessary for leading a righteous life.

It is worth mentioning that all the English translations of the verses cited in the current paper are adopted from Abdel Haleem (2010). Besides, for the sake of convenience, the quoted verses will be referred to by the number of Surah followed by the number of the verse.

Actually, Abdel Haleem's goal is to make his translation "accessible to everyone who speaks English" as well as maintain "accuracy, clarity, flow, and currency of 
language" (Abdel Haleem, 2010: xxix). Hence, he avoided archaism and cryptic language and used simple, readable contemporary English. Therefore, the text flows smoothly and reads easily. Overall, the translator tried hard to preserve the Arabic meaning by respecting the context of discourse and being for the most part faithful to the meaning and spirit of the original text.

\section{Theoretical Framework}

Investigation of pronoun reference may differ according to the theoretical framework employed in a given analysis, especially with respect to the interrelations between pronouns and their references on the one hand and the impact of these relations on the whole text on the other hand. The analytical approach to problem solving, which tends to break a problem down into smaller pieces in order to solve it, seems to be the most appropriate approach to be followed in this study.

\section{Lexical Reference and Semantic Reference}

Reference may occur based on two factors: lexical form or lexical meaning. As shown by Edeimah (1961:vol. $3: 286)$, reference to the lexeme of the pronouns mostly comes first, and then reference is made to the meaning of the pronouns. Consider the reference of the relative pronoun man 'who' in the following verse in (1) below:

(1) هُو (So, is someone who believes equal to someone who defies God? No, they are not equal.) (32:18) 
The nouns mu?minan 'believer' and faasiqan 'defiant' are in the singular form based on the lexeme of man 'who' and the pronoun in laa yastawwuun 'they are not equal' is in the plural based on the meaning of man 'who'. This interpretation is emphasized by the fact that the plural ?allaðiina ?aamanuu 'those who believe' and ?allaðiina fasaquu 'those who defy' are used in the following verses (32:19-20).

The possibility of using a plural verb with a single noun in Arabic goes in parallel with the concept of notional concord or agreement. Leech (2006:72) states that notional concord occurs when "the choice of verb form is determined more by the meaning of the subject than by the strict grammatical concord between singular and singular, plural and plural". He further illustrates that grammatical concord (i.e. a singular verb with a singular subject and a plural verb with a plural subject) may be broken and notional concord (i.e. a plural verb with a singular subject) may be observed "if the notion of plurality is present in the singular subject". Actually, this is the case with collective nouns where they "can be treated as either singular or plural, depending on context and meaning" (Kolln and Funk 2012:246).

Consider the following example from Leech (2006:72):

(2) a. The audience was impressed by his performance.

b. The audience were impressed by his performance.

In (2b) the audience takes a plural verb as it is thought of as consisting of a set of separate people. 
Actually, the verb alternates between singular and plural with collective nouns based on the dichotomy of form versus meaning. In (2a) the verb was agrees with the form of the word audience which is singular, while in (2b) were agrees with the meaning of audience which is plural.

Likewise, in verse (22:19) in (3) the noun xaSmaan 'two kinds of people' as the referent of the demonstrative pronoun for the masculine dual haaðaan 'these' is in the dual form based on the lexical form of the demonstrative haaðaan 'these'. However, the pronoun in the verb ?ixtaSamиu 'disagree' is put in the plural due to the meaning which indicates plurality.

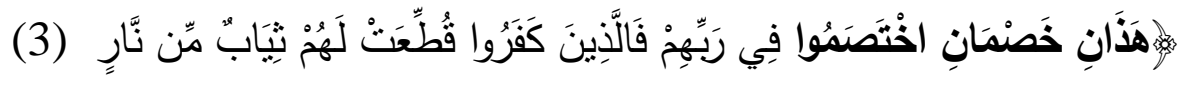

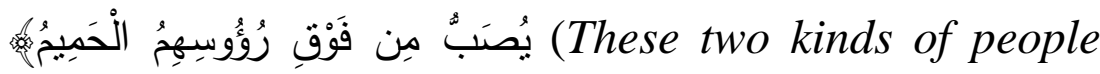
disagree about their Lord. Garments of fire will be tailored for those who disbelieve; scalding water will be poured over their heads.) (22:19)

Al-Zamakhshary (2009:692) explicates that the word xaSmaan means two opposing parties or groups and it is based on lexical form and ?ixtaSamuи is in the plural based on semantic meaning. This interpretation by AlZamakhshary is only a linguistic justification for the switch from the dual to plural form rather than figuring out the hidden secrets of such a switch or its relation to the context. Tabal (1998:99-100) illustrates that the reason behind this switch can be fathomed through considering the context. The current verse (22:19) is used to introduce the destiny of two parties: the believers and the disbelievers on the Day of Resurrection. Besides, in a previous verse (22:17) God tells 
us that the Day of Resurrection is the appointment when God will judge between the followers of the different sects and religions. Therefore, as Tabal concludes, those sects mentioned in the verse $(22: 17)$, (i.e. the believers, those who follow the Jewish faith, the Sabians, the Christians, the Magians, and the idolaters), will end up, after God will judge between them, into two parties: believers and disbelievers. Hence, they are referred to in the dual form xaSmaan, whereas, ?ixtaSamuu refers to their status and different beliefs in this world.

The same implications apply to verse (33:31) in (4) where reference is made in the masculine form based on the lexical form of the relative pronoun man 'who' in yaqnut 'obey' and is made in the feminine form based on the lexical meaning of man 'who' in taçmal 'do'.

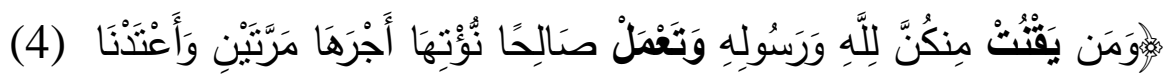

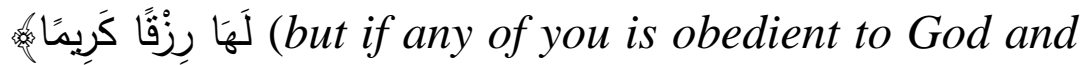
His Messenger and does good deeds, know that We shall give her a double reward and have prepared a generous provision for her.) (33:31)

It should be noted that the English translation does not reflect the contrast between the masculine form in yaqnut 'obey' and the feminine form in taçmal 'do' due to the fact that the second person pronoun you has neither gender nor number distinctions. The verses in (5) show switch between singular and plural as follows:

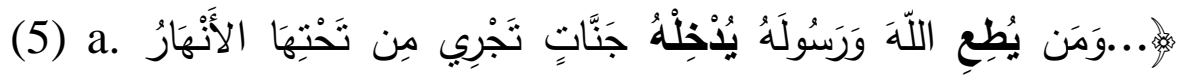
خَالالدينَ فِيهَا......God will admit those who obey Him 
and His Messenger to Gardens graced with flowing streams, and there they will stay...) (4:13)

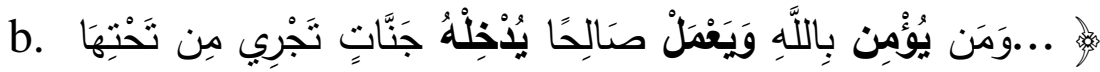

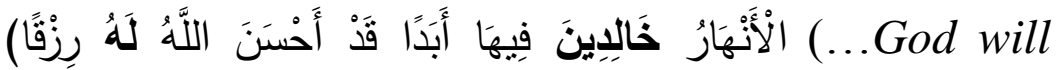
admit those who believe in Him and do righteous deeds into Gardens graced with flowing streams, where they will remain forever-He has made good provision for them.) (65:11)

In the verse $(4: 13)$ in $(5 a)$, the reference is switched from being based on the lexical form in yuTiç 'obey' and yudxilhu 'admit him' to lexical meaning in xaalidiina 'they will stay'.

More interestingly, there may be multiple switches in a single verse, i.e. from singular to plural then to singular once again. In (5b), switch is made from the singular in referring to the lexeme of the relative man 'who' in yu? min 'believe', yaçmal 'do' and yudxilhu 'admit him' to the plural xaalidiina 'they will remain forever' based on the lexical meaning of man 'who', and to the lexical form once again in lahu 'for him'. Put differently, reference is first made to the third person singular in yu?min 'believe', yaçmal 'do' and yudxilhu 'admit him'; then to third person plural in xaalidiina 'they will remain forever', and finally to third person singular once again in lahu 'for him'. The translation of the verse, however, sticks to one form, i.e. the plural form which is based on the meaning of man 'who'. This reflects how Abdel Haleem is considerate regarding the consistency of pronoun reference when rendering them all in the plural form. 
Moreover, a plural pronoun may be used to refer to two things as two semantically denotes plurality. In the verse in (6) reference is first made in the dual form in yahkumaan 'they gave judgement' as referring to the Prophets David and Solomon, then in the plural in liћukmihim 'to their judgement' while the reference is also made to the two prophets.

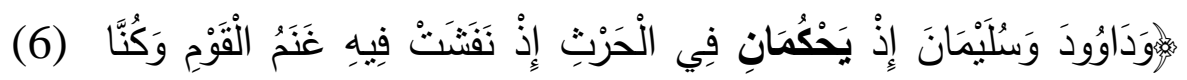

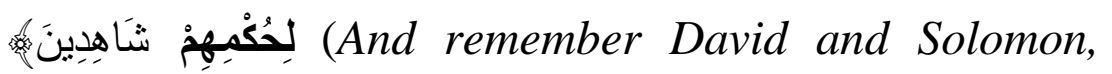
when they gave judgement regarding the field into which sheep strayed by night and grazed. We witnessed their judgement.) (21:78)

Examples from (4) to (6) above exhibit the phenomenon of Iltifaat or reference switching. It is one of the most interesting features of the Quranic style It refers to grammatical shifts between one personal pronoun and another, between singular and plural, between masculine and feminine, and between verb tenses. Switch in pronouns or reference switching is quite an established rhetorical practice in Arabic and it helps achieve a number of rhetorical effects.

Al-Zamakhsahry (2009:29) points out that "switching from one style to another in speech would enhance the attention of the hearer and renew his interest to listen more attentively than being delivered in one style. In addition, the context of each switching may have its own implications". Therefore, according to Al-Zamakhshary, switching has two main functions: a general one regarding catching the attention of the hearer and pleasing him; and a 
specific one regarding the contextual implications of each switch. Reference-switching adds to the sweetness of the discourse and provides subtle meanings that cannot be fathomed otherwise. According to Abdul-Raof (2001), reference switching is defined as the most common feature of Quranic discourse.

The main functions of reference-switching include the change of emphasis, alerting the reader to a particular matter, and enhancing the style of the text. Its effects include creating variation and difference in a text, generating rhythm and flow, and maintaining the readers' attention in a dramatic way.

Reference switching is a common style in Arabic but not in the English language. Therefore, as Al-Badani et al (2014:804) conclude, "the translator may have to intervene by inserting footnotes, providing translator's notes or creating explanatory paraphrases" in order that the target readers may feel the impact of reference switching as a linguistic phenomenon and a rhetorical style.

\section{Types of pronoun reference}

Pronouns can refer anaphorically or cataphorically as well as their referents can be realized endophorically or exophorically.

\subsection{Endophoric and Exophoric Reference}

As regards its realization in the text, pronoun reference is divided into two categories: endophoric and exophoric. According to Halliday and Hasan (1976), referring expressions that refer to something outside the text are said to have exophoric anaphora as contrasted with 
endophoric anaphora where the referents lie in the text. In other words, endophoric reference indicates that the referent of the pronoun is explicitly mentioned in the text, whereas in exophoric reference, the referent in not explicitly expressed in the text, i.e. the referring expressions refer to something outside the text but understandable from the context. For examples, it in the sentence it is unbelievable refers to something both interlocutors know about, i.e. shared knowledge, but not mentioned in the discourse. The following two verses show endophoric and exophoric reference, respectively:

(7) a. ..... (Noah called out to his Lord...) (11:45)

b. وَهَ (Your Lord has not forsaken you [Prophet], nor does He hate you.) (93:3)

In (7a) the underlined pronoun haa 'his' refers to the name Noah which is present in the text, while the underlined pronouns kaaf 'you and your' in (7b) refers to the prophet Muhammad, peace be upon him, without explicit mentioning of his name in the text.

Exophora refers to the use of pronouns or other referring expression to refer to someone or something outside the text. In such a case, the context of use is crucially important as the hearer/reader has to construct the context of the situation so as to figure out the referents (Halliday and Hasan 1976). For instance, in conversations, pronouns such as $I, y o u$, and we refer exophorically to the participants involved in the conversation. More specifically, the pronoun I refers to the speaker/writer, we 
to both the speaker/writer and another person/or other people not including the addressee(s), and you to the addressee(s). (see Meyer, 2010)

It is worth noting that, as Cook (1992) points out, there are cases of multi-exophoric you where the pronoun you refers to many people in the actual and fictional situation". Put differently, endophoric reference refer to someone or something within the text, whereas, exophoric reference refers to someone or something manifest to the participants from situation or from their mutual knowledge.

\subsection{Anaphoric and Cataphoric Reference}

Based on the position of the referent entity in the text, there are two types of reference: anaphoric reference and cataphoric reference. In the former the referring expression refers back in the discourse, i.e. it follows the referent, while in the latter it refers forward in the discourse, i.e. it precedes the referent. Accordingly, anaphora (backward reference) and cataphora (forward reference) are two types of endophora where reference is made to an item within the text itself. Consider the following examples from English and Arabic, respectively:

(8) a. John bought a new car last month. It was very expensive.

b. Before they left, Mr. and Mrs. Watson had signed the contract.

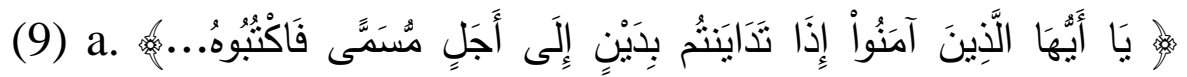
(You who believe, when you contract a debt for a stated term, put it down in writing...) (2:282) 


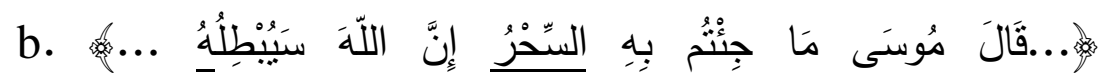
(...Moses said, 'Everything you have brought is sorcery and God will show it to be false...) (10:81)

c. فَأَوْجَسَ فِي نَفْسِهِ خِيفَة مُوسنَى (Moses was inwardly alarmed.) (20:67)

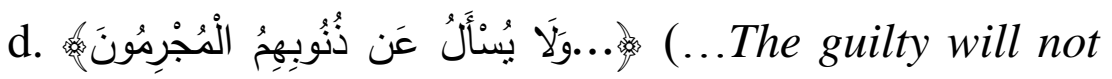
be questioned about their sins.) (28:78)

The examples in (8a) and (8b) illustrate anaphoric and cataphoric reference in English, respectively. In (8a) the pronoun $i t$ has a an anaphoric reference as it refers back to a new car, while in (8b) the pronoun they refers cataphorically to $M r$. and Mrs. Watson which are mentioned earlier in the text. In (9a) the pronoun haa 'it' refers back to ?addayn 'the debt', and in (9b) the pronoun haa 'it' refers back to ?assitr 'sorcery'. The underlined pronouns in $(9 \mathrm{c}-\mathrm{d})$ are representative of cataphoric reference. In (9c) the pronoun haa 'his' refers forward to Moses, peace be upon him, and the pronoun hum 'their' in (9d) refers forward to 'the guilty'. Cataphoric reference helps create suspense as the reader is left eager to recognize the referent of the cataphoric expression.

It is worth noting here that Damiiru šša?n (literally: matter or significance pronoun) or impersonal pronoun in Arabic is representative of cataphoric reference as the pronoun precedes its referent (the clause that follows it) and it is disambiguated by it. The pronoun haa 'it' in verse (22:46) in (10a) below refers cataphorically to people's eyes. This means, as explained by AlZamakhshari 
$(\nvdash \cdot 9: 79 \wedge)$, the matter is that people's eyes do not become blind.

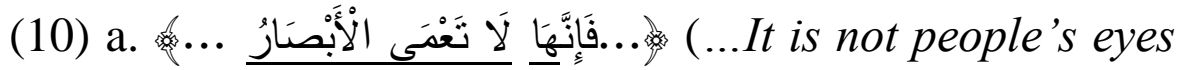
that are blind ...) (22:46)

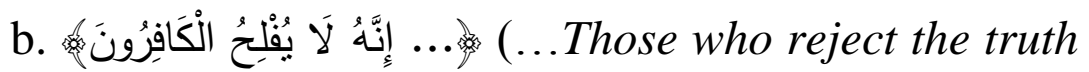
will not prosper.) (23:117)

The pronoun haa 'it' in (10b) implies stressing the proposition that the disbelievers never prosper. It is more emphatic than saying ?inna lkaafiriin laa yufliћuun 'the disbelievers will not prosper' as the pronoun sets the ground for the issue introduced in the verse in order to attract attention and arouse interest. In addition, the use of the impersonal pronoun in this way has its powerful effect on the hearer through the use of elegant, terse and welltailored expressions.

Starting discourse with a pronoun helps create a psychological disposition and establish metal frameworks to solve a puzzling situation. Besides, it attracts attention, raises awareness, and increases interest in what will be said later on. As put by Culpeper and Haugh (2014:33), the referring expression, in such a case, "flags the kind of context that needs fleshing out". Consequently, the impersonal pronoun Damiiru $̌ s ̌ a ? n$ is used as a device to arouse interest, create suspense and provoke curiosity. The impersonal pronoun Damiiru $\check{s} \check{s} a$ ? $n$ answers the question 'what is the matter or what is the state of affairs'. It denotes the significance, seriousness, and importance of the matter. According to Al-Zeyadi (2006: 296), the impersonal pronoun Damiiru šša?n occurs in about eighty-eight verses 


\section{Abul Hassan M. Abdelhameid}

either explicitly or implicitly to denote seriousness, significance, warning, promise, advice, and admonition.

It is obvious that the impersonal pronoun denotes certain rhetorical functions that are not conveyed otherwise. The question that addresses itself now is how can such functions be conveyed to the target reader. One answer to this question is that whenever a pronoun is used in the original text, it should be rendered by a pronoun in the target text. An alternative way is to use paraphrase whenever possible. Consequently, a suggested translation for the impersonal pronoun Damiiru $\check{s} \breve{s} a ? n$ in verse (23:117) above would be "it is indeed the disbelievers never prosper".

Cataphoric reference usually occurs with delayed subjects when the subject appears after the main verb and its empty position is usually filled with a dummy word such as it. Strumpf and Douglas (2004) assume that "sentences with delayed subjects always begin with a dummy it". In a sentence such as it is too late to go out, the true subject to go out is delayed to the end of the sentence and its place is filled with a dummy it. Otherwise, the sentence would read to go out is too late.

This use of dummy it with delayed subjects should not be confused with the use of it as a dummy subject in sentences about times, dates and the weather, e.g. it is late, it is Friday, it is hot. Dummy it is distinguished from the ordinary it in the sense that the former is an empty it that refers to nothing at all and simply fits a grammatical function, i.e. to fill out the obligatory slot of the subject. In 
other words, dummy it has a syntactic rather than a semantic function.

A dummy pronoun has no "identifiable meaning", i.e. it is a meaningless pronoun (Huddleston and Pullum 2007:70). Huddleston and Pullum (2007:218) state that " a dummy pronoun is one that has no independent meaning of its own but occurs in certain constructions simply to satisfy some syntactic requirements". It and there in the following sentences are dummy pronouns as they are "inserted to satisfy the requirement that finite clauses must contain a subject"

(11) a. It's likely that she'll go.

b. There's plenty of time.

Huddleston and Pullum (2007:247) further illustrate that "clauses with a subordinate clause subject generally have variants with the subordinate clause at the end and dummy it as subject". Dummy it is also known as anticipatory it, empty it, and non-referential it. In (12) below, (12b) is the dummy it variant of (12a):

(12) a. To give up now would be a mistake.

b. It would be a mistake to give up now.

Accordingly, the anticipatory it represents one type of cataphora for in such structures the pronoun it occupies the regular position of the subject of a sentence as a substitute for the postponed subject. As Nelson and Greenbaum (2016) point out, nominal clauses are not usual in the position of the subject of a sentence. Instead, the subject is usually moved to the end (i.e. the postponed 
subject) and its position is taken by it (i.e. the anticipatory it). This is exemplified by the sentences in (13) below where the (b) variant is more common. Moreover, the anticipatory it tends to shift emphasis to the verb or the noun phrase that follows the verb as exemplified in (14) below:

(13) a. That they canceled the concert is a pity.

b. It is a pity that they cancelled the concert.

(14) a. It took so long to solve the problem.

b. It does not matter to me who wins the race.

The subject can be implied in a present participle clause. According to Kolln and Funk (2012:149), the subject of the introductory participle phrase in a sentence should be "also the subject of the sentence and is located in regular subject position. Otherwise, the participle dangles", i.e. looks for a subject. Consider the following example of a delayed subject with a dangling participle from Kolln and Funk (2012:150):

(15) Knowing how much work I had to do yesterday, it was good of you to come and help.

In the previous sentence in (15) the subject of the participle is an implied you, however, it surfaces in the predicate rather than in the usual subject position. Kolln and Funk demonstrate that if the participle phrase is expanded into a complete clause, the delayed subject would appear in the normal subject position as follows: it was good of you to come and help yesterday when you learned how much work I had to do. 


\section{Identifying Pronoun Reference}

Pronoun reference can be identified in the light of certain syntactic and semantic rules. Ibn Al-Anbary, cited in Al-Zarkashy (1984, vol.4:24-42), wrote two volumes on pronouns in the Holy Quran. He tackled reasons beyond using pronouns and the identifications of the referents of pronouns. Based on his arguments on pronouns in the Holy Quran, pronouns reference can be identified according to the following rules:

\subsection{Implication}

The referent of a pronoun can be inferred from a verb or another noun in the text. In the examples in (16) the referent is implied in the verb, as illustrated by the following verse:

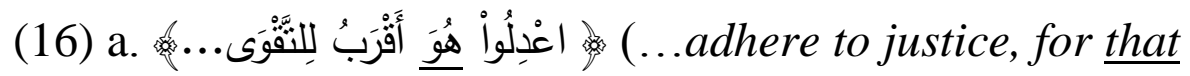
is closer to awareness of God...) (5:8)

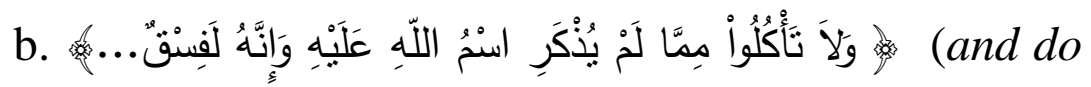
not eat anything over which God's name has not been pronounced, for that is breaking the law...) $(6: 121)$

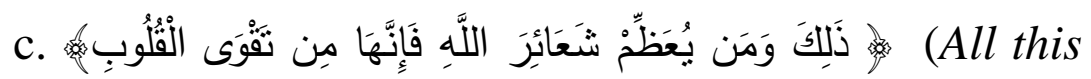
[is ordained by God]: those who honour God's rites show the piety of their hearts.) (22:32)

In (16a) huwa 'it' refers to ?alçadl 'justice' a noun inferred from the preceding verb ?içdiluu 'be fair or adhere to justice'. Similar instances include the verse $(6: 121)$ in (16b) where the pronoun haa 'it' refers to ?al?kl 'eating' implied in the verb laa ta?kuluu 'do not eat', and the verse 
(22:32) in (16c) where the pronoun haa 'it' refers to the noun taçžiim 'honor' which is implied in the verb yuçažžim 'to honor'.

However, in the English translation of the above verses, the translator preferred to use demonstratives instead of personal pronouns as he used the demonstrative pronoun that to render the pronouns mentioned in the verses in (16a-b) into English. In (16c) the translator did not use any pronoun at all. Yet, he used the verb show.

\subsection{Entailment}

The referent can be figured out through entailment, i.e. it is entailed from context. In (17) the referent soul is entailed by the mentioning of ?altulquum 'the throat' in (17a) and ?ittraqia 'the collarbone' in (17b) for the context is about death and nothing reaches the throat or the collarbone during dying except the soul. In (17c) the referent of the pronoun haa 'it' in yasarnaahu 'made it easy' refers to the Quran as indicated by making it easy in your language.

(17) a. a. (When the soul of a dying man comes up to his throat.) (56:83)

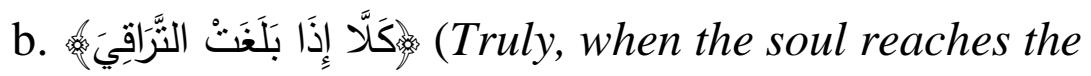
collarbone.) (75:26)

c. 家 have made it easy, in your own language [Prophet], so that you may bring glad news to the righteous and warnings to [a] stubborn people.) (19:97) 
The pronoun it in the translation of the verse should be replaced by its referent, i.e. the Quran. The explicit name is

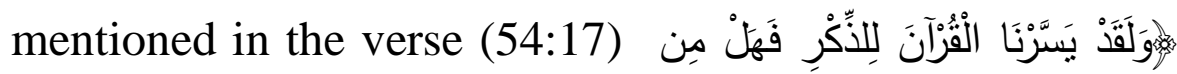
مُدَّكِ ف (We have made it easy to learn lessons from the Quran: will anyone take heed?). In addition, the referent in tubaššira 'bring glad news' and tunðira 'warn' is the Prophet

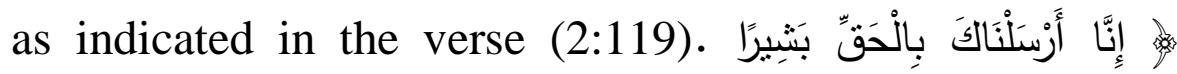
وَنَذَيرًا... (We have sent you [Prophet] with the truth, bearing good news and warning.) (2:119)

As shown by Culpeper and Haugh (2014:21), the connections between a reference point and the aspects of the situation in which the utterance takes place "rely heavily on the extralinguistic context to supply the referent". For instance, in a sentence such as it's me, the pronoun me refers to the speaker.

\subsection{Context}

The pronoun may be inferred by the context of the verse. For instance, the referent of haa 'it' in žahrihaa 'its surface' and çalayhaa 'on it' and in (18a) and (18b), respectively, refers to earth as inferred from the context.

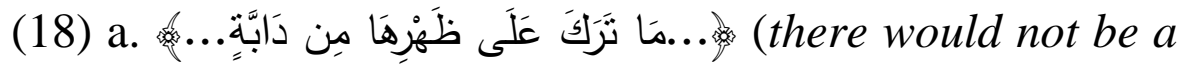
single creature left on the surface of the earth.) (ro: $\leqslant 0)$

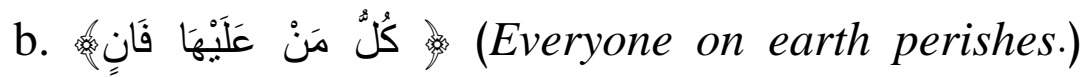
(55:26)

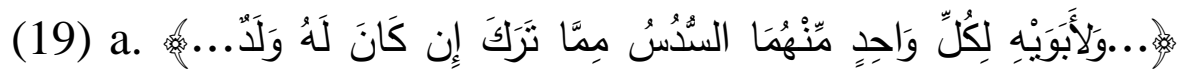
(Parents inherit a sixth each if the deceased leaves children.) (4:11) 


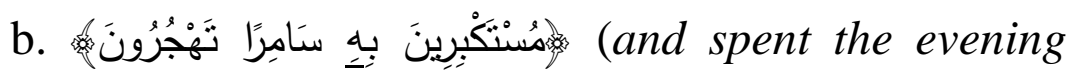
arrogantly making fun of [the Quran].) (23:67)

The underlined pronouns haa in (19a) in li?abawayhi 'for his parents' and lahu 'for him' refer to the deceased even if it was not previously mentioned. When God commands Muslims concerning their children, it is known from context that there would be a deceased who the pronoun would refer to. In (19b) the pronoun haa 'it' refers to the Quran as inferred from the context.

\subsection{Mental Association}

The pronoun may also refer to an implicit referent which is recalled to mind due to the mentioning of its concomitants. Consider the following:

. We (We had placed [iron] collars around their necks, right up to their chins so that their heads are forced up.) (36:8)

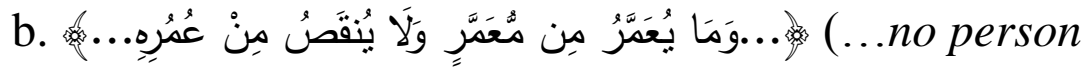
grows old or has his life cut short...) (35:11)

In (20a) the pronoun heya refers to their hands which are not mentioned explicitly and they come out to the foreground due to the concomitant relationship between chains and the hands. In other words, the use of chains recalls the image of hands to the mind. However, the translator had made no reference at all to the hands. The intended meaning, God knows best, as explained by Mujahed, as cited in AlQurtubi (1947, vol.15:9), is that 
their hands are tied up so that they are restrained from all good.

In (20b), the possessive pronoun haa 'his' in çumurihi 'his life' does not refer to the person who grows old. Instead, it refers to the person whose life cut short and which is understood from the juxtaposition relationship between the two persons (i.e. the one who grows old and the one whose life cut short). In other words, the mentioning of the person who grows old recalls to consciousness the person whose life cut short.

\subsection{Part-Whole Relationship}

The pronoun may refer to a part of what is previously mentioned. Examples include the following:

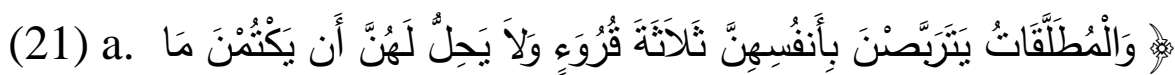

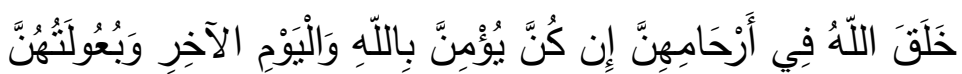

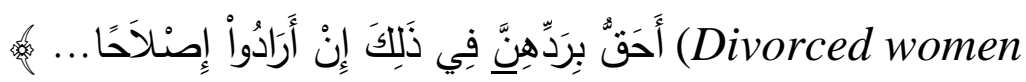
must wait for three monthly periods before remarrying, and, if they really believe in God and the Last Day, it is not lawful for them to conceal what God has created in their wombs: their husbands would do better to take them back during this period, provided they wish to put things right.) (2:228).

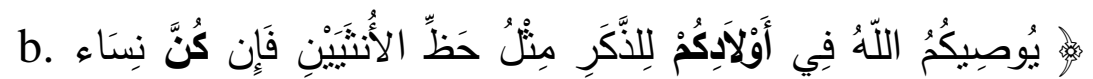

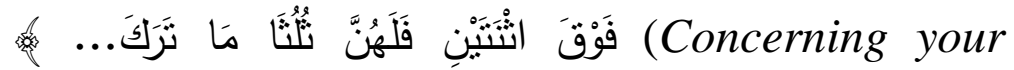
children, God commands you that a son should have the equivalent share of two daughters. If there 
are only daughters, two or more should share twothirds of the inheritance...) (4:11)

It is quite established that the right to take the divorced women back is restricted only to return divorce. Apparently, the pronoun henna 'them' in biradihinna 'take them back' in (21a) refers back to divorced women in general. However, it refers only to specific type of them excluding women who have received irrevocable divorce. Thus, reference is made to all women, yet only women with return divorce are specified. Likewise, in (21b) the pronoun in kunna 'they were', refers to daughters which are part of the children.

\subsection{Unspecific Referent}

The pronoun may not refer to a definite referent or a referent inferred from context or accompaniment relationship. In such a case, the pronoun reference is unspecific. Culpeper and Haugh (2014:22) point out that "deictic expressions can be used non-deictically", i.e. they do not have a particular referent; they rather have a generic usage. For example, there in a sentence like there is another answer to the question does not refer to a particular location, but it is used as a dummy subject to indicate the existence of something.

This generic usage of pronouns in English parallels some uses of Damiiru $\check{S} \breve{s} a ? n$ or impersonal pronoun in Arabic where the referent is unspecific. The pronoun in such instances is mainly used to arouse attention and to highlight the importance of what follows. Damiiru $\check{s} \breve{s} a$ ? $n$ is exemplified in (22) below: 


\section{The Syntax and Semantics of Pronoun Reference in the Holy Quran}

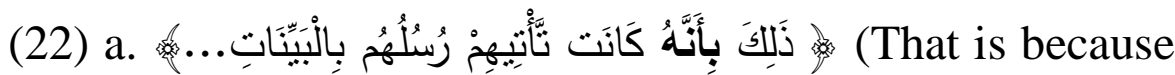
their messengers came to them with clear signs...) $(64: 6)$

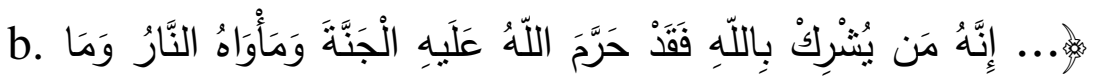
(If anyone associates others with God, God will forbid him from the Garden, and Hell will be his home. No one will help such evildoers.) $(5: 72)$

In the above examples, the translator did not render the Arabic pronoun at all. In (22a) he used the demonstrative pronoun as a subject and ignored the pronoun haa 'it' in ?innahu, and in (22b) he, rather moved directly to the conditional particle if without paying any attention to the pronoun that precedes it.

A suggested translation that is more faithful to the original and maintains the rhetorical effect of the impersonal pronoun might be 'that it is because' for in (22a) and 'It is he who associates others with God'

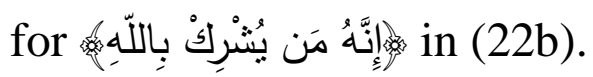

\subsection{Genre of the Referent}

The pronoun may refer to a lexeme or a word while it denotes the genre of the thing referred to or vice versa as exemplified in (23a) and (23b), respectively:

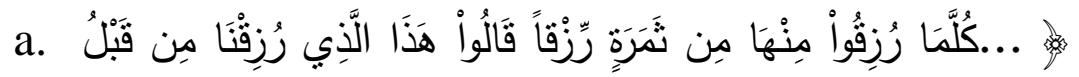

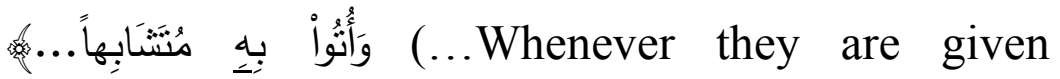
sustenance from the fruits of these Gardens, they will 
say, 'We have been given this before,' because they were provided with something like it..) (2:25)

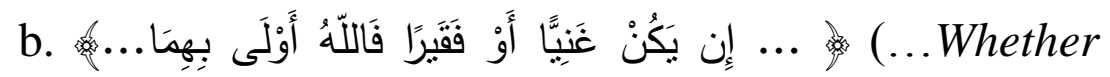
the person is rich or poor, God can best take care of both...) (4:135)

In (23a) the pronoun haa 'it' refers to what they have been provided in both the world life and the hereafter as 'We have been given this before,' includes what they have been given in both worlds. In (23b) had the reference been made to the lexeme, the pronoun bihimaa 'both of them' would have been singular, i.e. bihi 'it'. Thus, the pronoun refers to the genre or the nature of both being rich or poor. Alternatively, the meaning might be, God knows best, if the two opposing parties were rich or poor. In the latter case, the pronoun refers to meaning rather than lexeme. It might be conceived also that ?aw 'or' here refers to the diversity of opponents, i.e. different types of opponents.

\subsection{Selective Reference}

In case that there are two preceding referents and reference is made to only one of them, the pronoun can possibly refer either to the former or to the latter. Mostly the pronoun refers to the latter, i.e. the closest referent to the pronoun. Examples include the following:

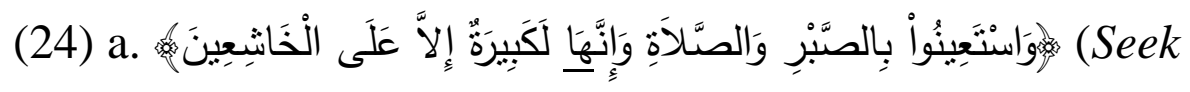
help with steadfastness and prayer- though this is hard indeed for anyone but the humble.) (2:45) 
b. اغِ مُوْْنِنَ (They swear by God in order to please you [believers]: if they were true believers, it would be more fitting for them to please God and His Messenger.) (9:62)

In the examples (24a) and (24b), the translator came up with an amazing rendering that incorporates both referents without any need to use pronouns. In (24a) he preferred to use a demonstrative pronoun that refers to a context that involves both steadfastness and prayer. In (24b) he reversed the order of the sentence and managed to do without pronouns at all. His translation of verse (9:62) in (24b) goes in accordance with, God knows best, the intended meaning, i.e. to please both God and His Messenger. Alternatively, if the pronoun refers to the closest of the two candidate referents, i.e. His Messenger, the meaning will be complete either. The Messenger is chosen for the reference as he is the caller to God and reporter of God's commands. God is mentioned in the verse for the sake of exaltation and the meaning is complete by mentioning only the Messenger.

The only instance where the pronoun refers to the first of two referents according to Ibn Al-Anbary, as quoted in Al-Zarkashy (1984:31), is in the verse (62:11) in (25) below:

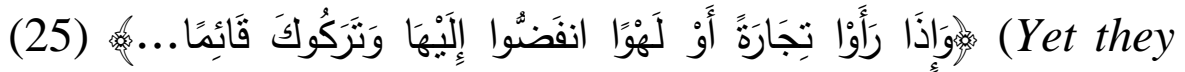
scatter towards trade or entertainment whenever they observe it, and leave you [Prophet] standing there...) (62:11) 
To conclude, as it has been shown in (24) above, it is a recurrent rule in Arabic that pronouns refer to the closer referents. However, this rule is broken whenever context necessitates otherwise, as in (25).

\subsection{A dual pronoun for a single referent}

The pronoun may occur in the dual case and it refers to only a single referent. In the verse $(55: 22)$ in $(26 a)$ the pronoun them refers to both fresh and salt bodies of water. However, pearls comes froth only from salt bodies of water. In (26b) the pronoun ?alef in nasiyaa 'they had forgotten' is in the dual form and it is only the servant who had forgotten the fish.

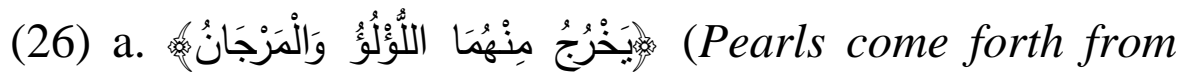
them: large ones, and small, brilliant ones.) $(55: 22)$

b. نَسِيَا حُونَهُمَا......they had forgotten all about their fish...) (18:61)

\subsection{Correlated Reference}

A pronoun may refer to an antecedent; however, its referent is something interrelated to it. Consider the following:

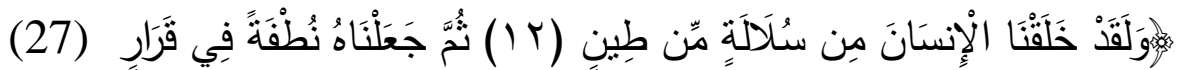
مَكِكين (1) (We created man from an essence of clay (12) then We placed him as a drop of fluid in a safe place (13)). (23:12-13).

Translating the pronoun in the word jaçalnaahu 'placed him' in verse (23:13) in (27) as if the pronoun haa? 
'him' refers to man is quite problematic and confusing for the target readers. One would inquire how man (i.e. the first man 'Adam') who is created from an essence of clay, could be placed as a drop of fluid in a safe place (i.e. the womb)! In order that the correct meaning could be conceived, the translator should bracket the actual referent of the pronoun in placed him, i.e. Adam's offspring as Adam himself was not created from a drop of fluid.

Another instance where the pronoun is related to something while indicating something else is the verse (22:78) in (28) below:

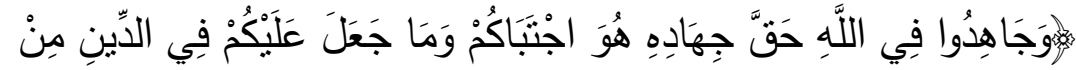

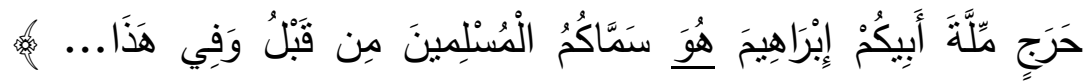
(Strive hard for God as is His due: He has chosen you and placed no hardship in your religion, the faith of your forefather Abraham. God has called you Muslims-both in the past and in this [message]...) (22:78)

It might occur to mind that the pronoun in huwa 'he' in He has called you Muslims in the past refers back to Abraham for it is the closer to the pronoun. Actually, such an interpretation is problematic and unsound. It is refutable for the fact that the demonstrative pronoun haaðaa 'this' refers to the Quran and the Quran was revealed centuries after Abraham. Consequently, the pronoun huwa 'he' in He has called you Muslims refers to God, i.e. God has called you Muslims in the previous Scriptures sent down to His Messengers and in this Quran sent down to Prophet Muhammad. Moreover, the focus of the discourse is God as 
Muslims are commanded to strive hard for God for He has chosen them and placed no hardship in their religion. Interestingly, this meaning is figured out by Abdel Haleem and is explicitly expressed in his English rendering of this verse as he bracketed message as a referent of the demonstrative this.

\subsection{Successive Pronouns}

If the pronouns came in succession, they had better refer to a single referent than different referents unless prescribed by meaning. Consider the following examples:

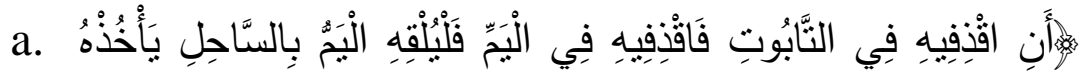

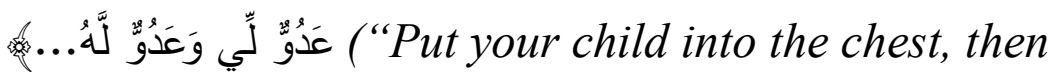
place him in the river. Let the river wash him on to its bank, and he will be taken in by an enemy of Mine and his. "...) (20:39)

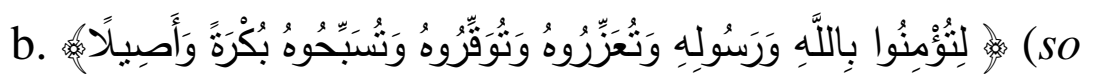
that you [people] may believe in God and His Messenger, support Him, honour Him, and praise Him morning and evening.) (48:9)

In (29a) the pronouns haa 'him' are more suitable to refer to Moses rather than partly to Moses and partly to the chest, i.e. the first pronoun haa in ?iqdifiihi 'put him' refers to Moses and the following in ?iqdifiihi 'place him', falulqihi 'wash him', ya?xuðhu 'take him' refer to the chest. Al-Zamakhshary (2009:655) criticizes relating successive pronouns to different referents and considers it alien to symmetry and contradictory to the inimitability of the Quran. He asserts that the one who is placed in the river 
and washed on to the bank is Moses inside the chest. According to him, this interpretation will unite the pronouns so that the flow of the speech would not be discontinuous.

Similarly, Al Zamakhshary (2009:1025) maintains that the pronouns haa 'Him' in in tuçazziruuhu 'support Him', tuwaqqiruuhu 'honor Him' and tusabbihuuhu 'praise Him' in the verse (48:9) in (29b) refer to God. The problematic pronoun in tuçazziruuhu 'support Him', according to $\mathrm{Al}$ Zamakhashry, means to support His religion and His Messenger. Other commentators (cf. AlQurtubi: 1947: vol. 16: 267) state that all the pronouns haa in these verbs refer to the Prophet except for the last, i.e. it refers to God.

However, in some cases, the meaning dictates that consecutive pronouns should have different referents. Examples include (18:22) and (16:100) as follows:

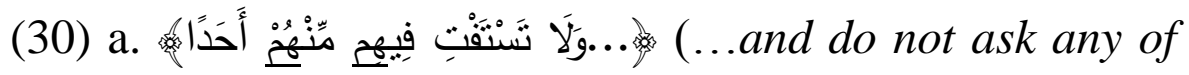
these people about them.) (18:22)

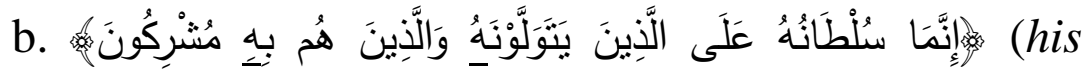
power is only over those who ally themselves with him and those who, because of him, join partners with God.) (16:100)

In (30a) the pronoun him 'them' in fiihim 'about them' refers to the people of the Cave, and hum 'them' in minhum 'any of them' refers to the Jews. In (30b) the pronoun haa 'him' in yatawallawnahu 'allay themselves with him' refers to Satan and the pronoun haa 'him' in bihii 'with him' refers to God. 


\subsection{Context Derived Reference}

Pronouns can be omitted and implied by context, for instance in the verse (22:20) in (31a) the pronoun their is omitted and inferred from the context. Hence, the rendering of ?aljuluud 'the skins' into English is more appropriately 'their skins' as done by Abdel Haleem. Similarly, ?alquluub 'the hearts' in (31b) means 'their hearts'.

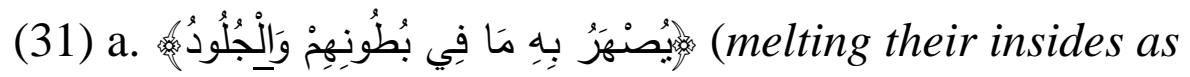
well as their skins.) (22:20)

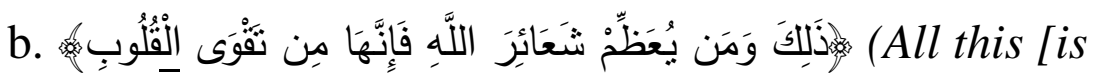
ordained by God]: those who honour God's rites show the piety of their hearts.) (22:32)

In the examples in (31) above, the definite particle in Arabic ?al 'the' is used to substitute a possessive adjective whose modified noun is already mentioned earlier in the verse.

\section{Conclusion}

As shown in this paper, pronoun reference can be realized either cataphorically or anaphorically as well as endophorically and exophorically. A number of syntactic and sematic rules for identifying pronoun reference in the Holy Quran have been investigated. Such rules include implication, entailment, context, mental association, partwhole relationship, selective reference, unspecific reference, and correlated reference.

Reference switching is quite frequent in the Holy Quran. Arabic allows for reference switching, whereas English does not. Reference switching in Arabic occurs in 
person, number and gender. Besides, Arabic can allow for both lexical and semantic reference. English is strictly limited in this respect as it permits semantic reference only with collective nouns.

Actually, the diversity in switching the type of referent (from singular to plural or from masculine to feminine or vice versa) is one of the features of the eloquence of the Holy Quran and one of the reasons of its cohesion and harmony. Nevertheless, when translating the meanings of the verse wherein such switching occurs, the translator may stick to one type of referent throughout the whole verse due to the difference in nature between English and Arabic one hand and the inimitability of the divine language of the Holy Quran on the other hand.

In order to render the switch in pronouns into English, Abdel Haleem often starts with the referent of the pronoun then relates other referents to it. In the verses (4:13) and (65:11) in (5) above, the translator starts with the antecedent (i.e. God), then relates all other references in the verse to this antecedent.

Furthermore, Arabic employs Damiiru $\check{s} s ̌ a ? n$ or impersonal pronouns to introduce significant and serious issues. English uses a dummy it which is an empty pronoun that fits in the subject position to render the verses including Damiiru $\check{s} \breve{s} a ? n$. Actually, the English empty it does not convey the rhetorical effect of Damiiru $\check{s} \check{S} a$ ? $n$ in Arabic. Paraphrase, as a translation strategy, is suggested in such cases. 


\section{List of the Phonemic Symbols Used to Represent the Arabic Data}

The phonemic symbols used to represent the Arabic data are listed below with their corresponding Arabic graphemes in parentheses:

[b] voiced bilabial stop

[ب]

[t] voiceless dento-alveolar stop $[ت]$

[T] voiceless dento-alveolar emphatic stop

[d] voiced dento-alveolar stop

[D] Voiced dento-alveolar emphatic stop

[k] voiceless velar stop

[q] voiceless uvular stop

[?] voiceless glottal stop

[j] voiced alveo-palatal affricate

[ћ] voiceless pharyngeal fricative

[ç] voiced pharyngeal fricative

[f] voiceless labio-dental fricative

$[\theta]$ voiceless inter-dental fricative

[ث]

$[ð]$ voiced inter-dental fricative

$[\gamma]$ voiced inter-dental emphatic fricative

[s] voiceless dento-alveolar fricative

[S] voiceless dento-alveolar emphatic fricative

[z] voiced dento-alveolar fricative

[̌̌ $]$ voiceless alveo-palatal fricative

[x] voiceless uvular fricative

[g $]$ voiced uvular fricative

[h] voiceless glottal fricative 
[r] voiced alveolar flap/trill (when geminated)

[1] voiced alveolar lateral

[m] voiced bilabial nasal

[n] voiced alveolar nasal

[y] voiced palatal glide

[w] voiced bilabial round glide

[i] high front vowel

[a] low back vowel

[u] high back rounded vowel

Note: Consonant gemination (tašdiid) and vowel lengthening are represented by doubling the respective consonant or vowel.

\section{References}

- ?alquraanu lkariimu [The Holy Quran].

- Abdel Haleem, M. A. S. (2010). The Quran: A New Translation. Oxford: Oxford University Press

- Abdul-Raof, H. (2001). Quran translation: Discourse, Texture and Exegesis. Britain: Curzon Press.

- Al-Badani, N. et al. (2014). "Reference Switching (Iltifāt) in Arabic and its Translation into English: An Intertextual Analysis". International Journal of Asian Social Science 4 (6): 791-805.

- Al-Qurtubi, S. (1947). ?al Jaamiçu li?aћkaami lquraan [Comprehensive Quranic Rules] (ed.) Salem Mustafa Al-Badri. Beirut: Dar Al-Kutub Al-Elmiya.

- Al-Zamakhshary, J. M. (2009). ?alkaššaaf [The Revealing]. Beirut: Dal Al-Marifa

- Al-Zarkashy, B. (1984). ?al-burhaanu fii çuluumi l-quraan [The Proof in Quranic Scineces], Muhammad Abu al- Fadl Ibrahim (ed.), Cairo: Dar al-Turath. 
- Al-Zeyady, E. N. (2006). Damiiru šša?ni fii lquraani lkariimi: draasatun nahwiyyatun balaagiyyatun [The Impersonal Pronoun in the Holy Quran: A Syntactic-Rhetorical Study]. Karbalaa Scientific Journal 4 (3) rrV-rVo.

- Cook, G. (1992). The Discourse of Advertising. New York: Routledge.

- Crystal, D. (2008). A Dictionary of Linguistics \& Phonetics. 6th ed. Oxford: Blackwell Publishing Ltd.

- Culpepr, J. and M. Haugh. (2014). Pragmatics and the English Language. Basingstoke: Palgrave Macmillan.

- Edeimah, M. A. (1961). diraasaatun li ?usluubi lquraani lkariimi [Studies on the Style of The Holy Quran]. Cairo: Darul Hadith.

- Nelson, G. and S. Greenbaum. (2016). An Introduction to English Grammar. London and New York: Routledge.

- Halliday, M. A. K. and R. Hasan. (1976). Cohesion in English (English Language Series 9) London and New York: Longman.

- Huddleston, R. and G. K. Pullum. (2007). A Student's Introduction to English Grammar. Cambridge: Cambridge University Press.

- Kolln, M. and R. Funk. (2012). Understanding English Grammar. 9th ed. Boston: Pearson.

- Leech, G. (2006). A Glossary of English Grammar. Edinburgh: Edinburgh University Press Ltd.

- Tabal, H. (1998). ?usluubu 1?iltifaati fil balaagati lquraaniyyati [Reference Switching in Quranic Rhetoric]. Cairo: Darul Fikr AlArabi

- Strumpf, M. and A. Douglas. (2004). The Grammar Bible: Everything You Always Wanted to Know About Grammar But Dind't Know Whom to Ask. New York: Owl Books, Henry Holt and Company, LLC. 